\title{
Litterfall dynamics after a typhoon disturbance in a Castanopsis cuspidata coppice, southwestern Japan
}

\author{
Tamotsu SATO ${ }^{\mathrm{a}, \mathrm{b} *}$ \\ a Kyushu Research Center, Forestry and Forest Products Research Institute (FFPRI), 4-11-16 Kurokami, Kumamoto, Kumamoto 860-0862, Japan \\ b Present address: Department of Forest Vegetation, Forestry and Forest Products Research Institute (FFPRI), PO Box 16, Tsukuba Norin, \\ Tsukuba, Ibaraki 305-8687, Japan
}

(Received 11 April 2003; accepted 3 September 2003)

\begin{abstract}
Litterfall was measured for eight years (1991-1998) in a Castanopsis cuspidata coppice forest in southwestern Japan. An extraordinarily strong typhoon (T9119) hit a study site in September 1991 and caused defoliation. The mean annual total litterfall was 6.0 t.ha ${ }^{-1}$ but annual variations (maximum-minimum ratio: 3.9) were very large throughout the observation period. The high ratio of annual fluctuation can probably be explained by a combination of coppice stand structure and presence of typhoon disturbance. The leaf litterfall formed the bulk of total litterfall and showed bimodal peak; leaf abscission in spring (April-May) and facultative peak in late summer (July-September). Small wood (less than $2 \mathrm{~cm}$ in diameter) input were associated with typhoon disturbances and showed no clear seasonality. Over the 7 years period following T9119, annual leaf input had recovered to $94 \%$ of pre-disturbance values. The recovery of leaf litterfall would be achieved with releafing of typhoon survivors.
\end{abstract}

Castanopsis cuspidata / litterfall / typhoon disturbance / coppice / recovery

Résumé - La dynamique de la chute de litière après une perturbation tourbillonnaire dans un taillis de Castanopsis cuspidata dans le sud-ouest du Japon. La chute de litière a été mesurée pendant huit années (1991-1998) dans une forêt de taillis de Castanopsis cuspidata dans le sud-ouest du Japon. Un typhon d'une force extraordinaire (T9119) s'est abattu sur notre site d'étude en septembre 1991 et a provoqué une défoliation. La chute de litière totale moyenne annuelle était de $6,0 \mathrm{t} \cdot \mathrm{ha}^{-1}$, cependant l'oscillation annuelle a grandement varié pendant toute la durée de l'observation. Le ratio élevé entre la chute de litière maximale et minimale $(3,9)$ peut probablement s'expliquer par une combinaison de la structure du peuplement des taillis et de la perturbation tourbillonnaire. La chute des feuilles composait la majeure partie de la chute de litière totale et indiquait une variation saisonnière bi-modale, avec une chute de feuilles au printemps (avril-mai) et un maximum facultatif en fin d'été (juillet-septembre). La production de petit bois (branches de moins de $2 \mathrm{~cm}$ de diamètre) était associée aux perturbations tourbillonnaires et n'indiquait aucun caractère saisonnier évident. Sur la période de sept ans qui a suivi le T9119, la production annuelle du feuillage est revenue à $94 \%$ de la valeur d'avant la perturbation. Le recouvrement des chutes de feuilles s'est effectué à partir des brins qui avaient résisté au typhon.

Castanopsis cuspidata / chute de litière / perturbation tourbillonnaire / taillis / recouvrement

\section{INTRODUCTION}

The short-term pulsed input of fine litterfall after typhoon disturbance is well documented in lucidophyllous (warm temperate evergreen broad-leaved) forests of eastern Asia [7, 25].

The importance of typhoon disturbance in affecting the structure and regeneration of lucidophyllous forest ecosystems is widely acknowledged $[3,21,30,48]$. On the other hand, the rate of forest reorganization of litterfall and productivity following severe typhoon disturbances are less well understood because most studies document only short-time post-disturbance patterns. Ecosystem studies in Puerto Rican wet subtropical forests show that responses to severe disturbance vary in different ecosystem components: i.e. forest floor biomass, soil nutrient pool, net production, fine litterfall, animal population, etc. [51]. These differences in the recovery process imply that long-term observation of ecosystem components is important in ecosystem studies after severe disturbance.

In southwestern Japan, Castanopsis cuspidata (Thunb.) Schottky is a common evergreen broad-leaved species that is widely distributed in secondary forests [9, 22]. Castanopsis cuspidata has good sprouting ability, and is used as firewood and to make charcoal under a 15- to 30-year rotation [34, 49]. However, other fuel resources have replaced firewood and

\footnotetext{
* Corresponding author: satoo@affrc.go.jp
} 
Table I. Changes of stand structure in Castanopsis cuspidata stand at Kumamoto, Japan. Trees are defined as having a height more of than $1.3 \mathrm{~m}$. Data from FFPRI $[4,5]$.

\begin{tabular}{|c|c|c|c|}
\hline \multirow{2}{*}{ Forest structure variables } & \multicolumn{3}{|c|}{ Year } \\
\hline & 1990 & 1994 & 1998 \\
\hline \multicolumn{4}{|l|}{ Tree density $\left(\mathrm{n} \cdot \mathrm{ha}^{-1}\right)$} \\
\hline Less than $4 \mathrm{~cm}$ in $\mathrm{DBH}$ & 8300 & 7450 & 4350 \\
\hline $4 \mathrm{~cm}$ to $18 \mathrm{~cm}$ in $\mathrm{DBH}$ & 1400 & 1525 & 1325 \\
\hline More than $18 \mathrm{~cm}$ in $\mathrm{DBH}$ & 660 & 660 & 690 \\
\hline Total & 10360 & 9635 & 6365 \\
\hline $\begin{array}{l}\text { Density of post-T9119 regeneration } \\
\text { tree }\left(n \cdot h^{-1}\right)^{*}\end{array}$ & - & 1700 & 600 \\
\hline Tree basal area $\left(\mathrm{m}^{2} \cdot \mathrm{ha}^{-1}\right)$ & 46.6 & 47.9 & 48,7 \\
\hline Tree volume $\left(\mathrm{m}^{3} \cdot \mathrm{ha}^{-1}\right)$ & 338.5 & 332.7 & 354.0 \\
\hline Maximum tree height (m) & 18.5 & 20.4 & 21.2 \\
\hline Mean tree height $(\mathrm{m})^{* *}$ & 16.8 & 17.3 & 17.5 \\
\hline Mean DBH $(\mathrm{cm})^{* *}$ & 23.1 & 24.7 & 26.4 \\
\hline
\end{tabular}

* Post-T9119 regeneration trees, comprised trees having less than $1 \mathrm{~cm}$ in DBH, were emerged after T9119 disturbance, September 1991. Density of post-T9119 regeneration trees decreased from 1700 to 600 between 1994 and 1998 . ** Values calculated from top 30 trees in tree height.

charcoal in the last 50 years; therefore, most Castanopsis coppice forests have been abandoned $[6,28,32]$. Currently, these abandoned coppices have reached a stand age of 40-50 years and $20 \mathrm{~m}$ in tree height without any silvicultural management and have covered large areas in southwestern Japan [6].

Over the last few decades, the role of these abandoned coppices has changed from wood production to environmental contribution to species biodiversity, aesthetic quality of the landscape and recreation areas [6]. Because Castanopsis trees over 50 years old are more susceptible to typhoon disturbance due to trunk rot fungus [40] and thread blight disease [19], new management methods are needed to develop usage of abandoned coppices under typhoon disturbance. Thus, understanding the subsequent pattern of litterfall, one of the major ecosystem components affecting productivity and nutrient cycling, after disturbance is important for improving abandoned coppice management.

On 27 September 1991, a record-breaking typhoon struck a large area of western Japan [47], causing serious damage to forests $[8,27]$. This typhoon provided a unique opportunity to study the litterfall pattern associated with severe disturbance. This paper documents how one strong typhoon alters the pattern of litterfall in an abandoned Castanopsis cuspidata coppice in southwestern Japan.

\section{MATERIALS AND METHODS}

\subsection{Study area}

The study was conducted in the experimental forest of the Kyushu Research Center, Forestry and Forest Products Research Institute (FFPRI), Kumamoto City, southwestern Japan. The study site (0.78 ha) was on a southwest-facing slope of Mt. Tatsuta (152 m a.s.l.; 32 $49^{\prime} \mathrm{N}$, $130^{\circ} 44^{\prime}$ E). According to the climatic data collected at the Kumamoto Local Meteorological Observatory ( $38 \mathrm{~m}$ a.s.1.), $2.5 \mathrm{~km}$ west of the site, the mean annual temperature is $16.2^{\circ} \mathrm{C}$, and the annual precipitation is $1967.8 \mathrm{~mm}$ [18]. About $40 \%$ of the annual precipitation is concentrated in the rainy season (June-July).

The site was a coppice stand that originated after clearcutting in 1951. The evergreen broad-leaved species Castanopsis cuspidata predominated in the site although there were a few other evergreen species, such as Quercus glauca Thunb. and Symplocos lucida Sieb. et Zucc. This stand is located at $90 \mathrm{~m}$ a.s.l. on weakly dried brown forest soil formed from andesite. In 1961, thinning was conducted once at the site, then 10-year-old coppicing, to set up experimental plots with different densities [37]. The primary production of the young Castanopsis cuspidata stand was estimated using these experimental plots between 1961 and 1967 [35, 36, 38, 39]. There has been no record of coppice management since then. With over 30 years of abandoned management, the amount of multiple-stemmed sprout clumps seriously decreased, and most of the trees had single stems at the beginning of this study.

In 1990, a 0.1 ha plot was set up within the site for monitoring acid rain and air pollution. Although this 0.1 ha plot lies on former experimental plots that had different densities after thinning, there were no clear differences among the former plots in 1990 [37]. Three tree censuses have been conducted in the plot since 1990. Table I summarizes the results of stand structure in the plot during the observation period (1991-1998) [4, 5].

\subsection{Typhoon record}

According to the definition of the Japan Meteorological Agency, a tropical cyclone with maximum sustained surface winds exceeding $17.2 \mathrm{~m} \cdot \mathrm{s}^{-1}$ is a "typhoon," and the area with maximum sustained surface winds of $15 \mathrm{~m} \cdot \mathrm{s}^{-1}$ or more is considered the typhoon area [44]. In this study, the study area was considered to have been struck by a typhoon when the eye of the typhoon passed within $200 \mathrm{~km}$ of Kumamoto City. Nineteen such typhoons were observed within the observation period. All of the typhoons were observed between July 
Table II. Composition of litterfall $\left(\mathrm{t} \cdot \mathrm{ha}^{-1} \cdot \mathrm{year}^{-1}\right)$ during the measurement period (1991-1998) in Castanopsis cuspidata coppice at Kumamoto, Japan. Values within parentheses represent percentage of each fraction.

\begin{tabular}{|c|c|c|c|c|c|c|c|c|c|c|}
\hline & \multirow{2}{*}{$\frac{\begin{array}{c}\text { Typhoon } \\
\text { disturbance }\end{array}}{1991}$} & \multicolumn{8}{|c|}{ Post-typhoon } & \multirow[b]{2}{*}{ Max/Min } \\
\hline & & 1992 & 1993 & 1994 & 1995 & 1996 & 1997 & 1998 & $\begin{array}{c}\text { Mean } \\
(1991-1998)\end{array}$ & \\
\hline $\begin{array}{l}\text { Number of strong } \\
\text { typhoons }^{(1)}\end{array}$ & 2 & 0 & 2 & 0 & 0 & 1 & 0 & 0 & - & - \\
\hline Leaves & $\begin{array}{c}4.32 \\
(39.1)\end{array}$ & $\begin{array}{c}1.70 \\
(59.2)\end{array}$ & $\begin{array}{c}2.82 \\
(52.7)\end{array}$ & $\begin{array}{c}3.94 \\
(73.7)\end{array}$ & $\begin{array}{c}2.53 \\
(60.6)\end{array}$ & $\begin{array}{c}5.15 \\
(64.3)\end{array}$ & $\begin{array}{c}3.99 \\
(76.1)\end{array}$ & $\begin{array}{c}4.57 \\
(77.0)\end{array}$ & $\begin{array}{c}3.63 \\
(60.5)\end{array}$ & 3.03 \\
\hline Small wood ${ }^{(2)}$ & $\begin{array}{c}5.71 \\
(51.7)\end{array}$ & $\begin{array}{c}0.75 \\
(26.3)\end{array}$ & $\begin{array}{c}1.79 \\
(33.5)\end{array}$ & $\begin{array}{l}0.35 \\
(6.5)\end{array}$ & $\begin{array}{l}0.32 \\
(7.6)\end{array}$ & $\begin{array}{c}1.03 \\
(12.8)\end{array}$ & $\begin{array}{l}0.44 \\
(8.4)\end{array}$ & $\begin{array}{l}0.59 \\
(9.9)\end{array}$ & $\begin{array}{c}1.37 \\
(22.9)\end{array}$ & 17.99 \\
\hline Reproductive parts & $\begin{array}{l}0.25 \\
(2.2)\end{array}$ & $\begin{array}{l}0.02 \\
(0.8)\end{array}$ & $\begin{array}{l}0.18 \\
(3.4)\end{array}$ & $\begin{array}{c}0.64 \\
(12.0)\end{array}$ & $\begin{array}{c}0.90 \\
(21.6)\end{array}$ & $\begin{array}{c}1.26 \\
(15.7)\end{array}$ & $\begin{array}{l}0.34 \\
(6.6)\end{array}$ & $\begin{array}{l}0.32 \\
(5.5)\end{array}$ & $\begin{array}{l}0.49 \\
(8.2)\end{array}$ & 55.38 \\
\hline Miscellaneous & $\begin{array}{l}0.77 \\
(7.0)\end{array}$ & $\begin{array}{c}0.39 \\
(13.7)\end{array}$ & $\begin{array}{c}0.56 \\
(10.4)\end{array}$ & $\begin{array}{l}0.42 \\
(7.9)\end{array}$ & $\begin{array}{c}0.43 \\
(10.3)\end{array}$ & $\begin{array}{l}0.57 \\
(7.1)\end{array}$ & $\begin{array}{l}0.47 \\
(8.9)\end{array}$ & $\begin{array}{l}0.45 \\
(7.6)\end{array}$ & $\begin{array}{l}0.51 \\
(8.5)\end{array}$ & 1.96 \\
\hline Total & $\begin{array}{c}11.05 \\
(100.0)\end{array}$ & $\begin{array}{c}2.87 \\
(100.0)\end{array}$ & $\begin{array}{c}5.35 \\
(100.0)\end{array}$ & $\begin{array}{c}5.35 \\
(100.0)\end{array}$ & $\begin{array}{c}4.18 \\
(100.0)\end{array}$ & $\begin{array}{c}8.00 \\
(100.0)\end{array}$ & $\begin{array}{c}5.24 \\
(100.0)\end{array}$ & $\begin{array}{c}5.94 \\
(100.0)\end{array}$ & $\begin{array}{c}6.00 \\
(100.0)\end{array}$ & 3.85 \\
\hline
\end{tabular}

(1) Typhoon with maximum sustained surface winds of more than $15 \mathrm{~m} \cdot \mathrm{s}^{-1}$ in Kumamoto city is defined as a strong typhoon.

(2) Branches less than $2 \mathrm{~cm}$ in diameter.

and September, except one in June 1997 and one in October 1998. This study defines the "typhoon period" as the months between June and October.

Only five typhoons reached maximum sustained surface winds exceeding $15 \mathrm{~m} \cdot \mathrm{s}^{-1}$ in Kumamoto City [18]. On 27 September 1991, an extraordinary typhoon (T9119), one of these five strong typhoons, hit a large area of western Japan. The local maximum instantaneous wind speed of T9119 was $52.6 \mathrm{~m} \cdot \mathrm{s}^{-1}$ at the Kumamoto Local Meteorological Observatory [47]. Based on the local maximum instantaneous wind speed, T9119 was the most powerful typhoon ever recorded at the Kumamoto Local Meteorological Observatory [47]. The other four strong typhoons were the following: T9117 in September 1991, T9306 in July 1993, T9313 in September 1993 and T9612 in August 1996.

\subsection{Litterfall collection}

Litterfall was collected in $0.58 \mathrm{~m}^{2}$ circular traps placed about $1.3 \mathrm{~m}$ above ground level. Ten traps were placed in the site, and accumulated litter was collected monthly. Each sample collected was separated into four fractions as recommended by Proctor [29]: (i) leaves, (ii) small wood (branches less than $2 \mathrm{~cm}$ in diameter), (iii) reproductive parts (flowers and seeds), and (iv) miscellaneous, which included bud scale, frass, bark, and dead animal bodies. Samples were then oven-dried at $70{ }^{\circ} \mathrm{C}$ for $72 \mathrm{~h}$, and their dry weight was recorded. The observation period was from July 1990 to December 1998. Since data for only six months were available in 1990, I estimated the annual litterfall input since 1991. Because there is wide agreement that a $2-\mathrm{cm}$ diameter is a reasonable upper limit for collecting woody litterfall in small traps [29], large branches ( $>2 \mathrm{~cm}$ in diameter) were not considered in this study.

To compare litterfall fluctuation before and after the T9119 disturbance, I estimated litterfall input before T9119 using data from Kaminaka [11] and his unpublished data (Kaminaka, personal communication). These data were obtained from a similarly aged (ca. 50 years) Castanopsis cuspidata stand near the study site. This adjacent stand has almost same average tree height and DBH values as the study site [11].
Proctor [29] points out that wood size limits vary among studies, so wood litterfall must be compared with caution. Since Kaminaka [11] does not mention excluding branches larger than $2 \mathrm{~cm}$ in diameter, it was difficult to compare small wood litter before and after the T9119 disturbance. In contrast, the leaf fraction is usually the best defined [29]; consequently, only leaf input before and after the T9119 disturbance was compared.

\subsection{Statistical analysis}

To compare differences in leaf input between seasons, the following categories were defined. First, monthly input during the typhoon period (June-October, $n=40$ ) was extracted from all data during the observation period (1991-1998, $n=96)$. The extracted data were then divided into two categories: input with typhoon records $(n=14)$ and input without typhoon records $(n=26)$. The remainder of the combined data was also divided into a further two categories: the spring period (AprilMay, $n=16$ ) and the autumn-winter period (November-March, $n=40$ ). These four categories (spring period, autumn-winter period, input with typhoon records and input without typhoon records) were tested using the non-parametric Kruskal-Wallis test followed by Scheffe's F-test.

The differences between annual leaf input were analyzed using the Kruskal-Wallis test. Following the Kruskal-Wallis test, Dunnett's test was used to compare the pre-T9119 value to the mean values of other years. The 0.05 probability level was used for all comparisons. All statistical analyses were carried out using StatView software (SAS Institute Inc., Cary, NC, USA).

\section{RESULTS}

\subsection{Annual fluctuation in litterfall}

Throughout the observation period (1991-1998), the mean total litterfall was $6.0 \mathrm{t} \cdot \mathrm{ha}^{-1} \cdot \mathrm{year}^{-1}$ at the site. Total litterfall varied, and the ratio of maximum to minimum was 3.9:1 (Tab. II). 
A maximum mass exceeding $10 \mathrm{t} \cdot \mathrm{ha}^{-1}$ was recorded in 1991. Nearly $70 \%$ of the total mass fell between July and September, when five typhoons, including T9119, were recorded. The daily leaf input in September $1991\left(3.03 \mathrm{~g} \cdot \mathrm{m}^{-2} \cdot\right.$ day $\left.^{-1}\right)$ was 1.8 times the average input of the pre-T9119 period calculated from Kaminaka [11, personal communication]. In 1992, the total litterfall decreased drastically, in spite of three typhoons in August. The total mass in 1993 was nearly twice that in 1992. As in 1991, the increment in the total mass was due to the four typhoons recorded between July and September, and $49.2 \%$ of the total 1993 mass fell in this period. In 1996, total litterfall reached $8 \mathrm{t} \cdot \mathrm{ha}^{-1}$ with a record-strong typhoon (Tab. II). These annual fluctuations indicate that increases in total litterfall are associated with strong typhoons.

Leaf litterfall formed the bulk of the total litterfall, averaging $60.5 \%$ of the total (range 39.1 to $77.0 \%$ ) (Tab. II). In 1991, small wood contributed a remarkable percentage, more than $50 \%$ of the total litterfall. Small wood exceeding $1 \mathrm{t} \cdot \mathrm{ha}^{-1}$ was also recorded in 1993 and 1996. Each of these high values was associated with strong typhoons. The reproductive parts, which are mainly the flowers and nuts of Castanopsis cuspidata, were the smallest fraction at the site, except in 1994, 1995 and 1996. Compared with the other fractions, "miscellaneous" had a smaller annual fluctuation in percentage and mass (Tab. II).

\subsection{Seasonal fluctuation in litterfall}

Leaf input showed bimodal distribution each year (Fig. 1) and significant differences between seasons (Fig. 2a; KruskalWallis test, $P<0.0001$ ). The first peak (April-May) averaged $35 \%$ of the annual input and ranged from 23 to $47 \%$. The second peak almost coincided with the typhoon period (June-October). Although leaf input with typhoon disturbances was not significantly higher than input without typhoon disturbances (Scheffe's F-test, $P>0.05$ ), increase in leaf input coincided with typhoon disturbances (Fig. 2a). Occasionally, there was a second peak without a typhoon disturbance (e.g., August-September 1994, September 1996 and August-September 1998). Theses peaks coincided with high temperatures and less precipitation (Fig. 1).

The seasonal pattern of small wood fall was clearly related to typhoon disturbances (Figs. 1 and 2b; Kruskal-Wallis test, $P<0.0001$ ). During the typhoon season (June-October), the small wood input increased significantly with typhoon disturbances (Fig. 2b; Scheffe's F-test, $P<0.05$ ).

The reproductive parts showed clear seasonal peaks that occurred in May for the flowers and from October to December for the nuts. Since it takes two years for Castanopsis cuspidata nuts to mature [17], a large pulse in the nut input followed the mass production of flowers the previous year (e.g., increased flower input in 1995 led to increased nut input in 1996).

Miscellaneous input includes bud scales that fall after new leaves flush between April and May. From August to October in 1990, a remarkable herbivory event was observed due to an infestation of tea bagworm (Eumeta minuscula) in the site. Most of the miscellaneous input during this period, amounting to $1.1 \mathrm{t} \cdot \mathrm{ha}^{-1}$, was tea bagworm frass. The consumption of leaves was estimated from the amount of frass using the following equation [50]:

$$
L w=1.7 E^{0.964}
$$

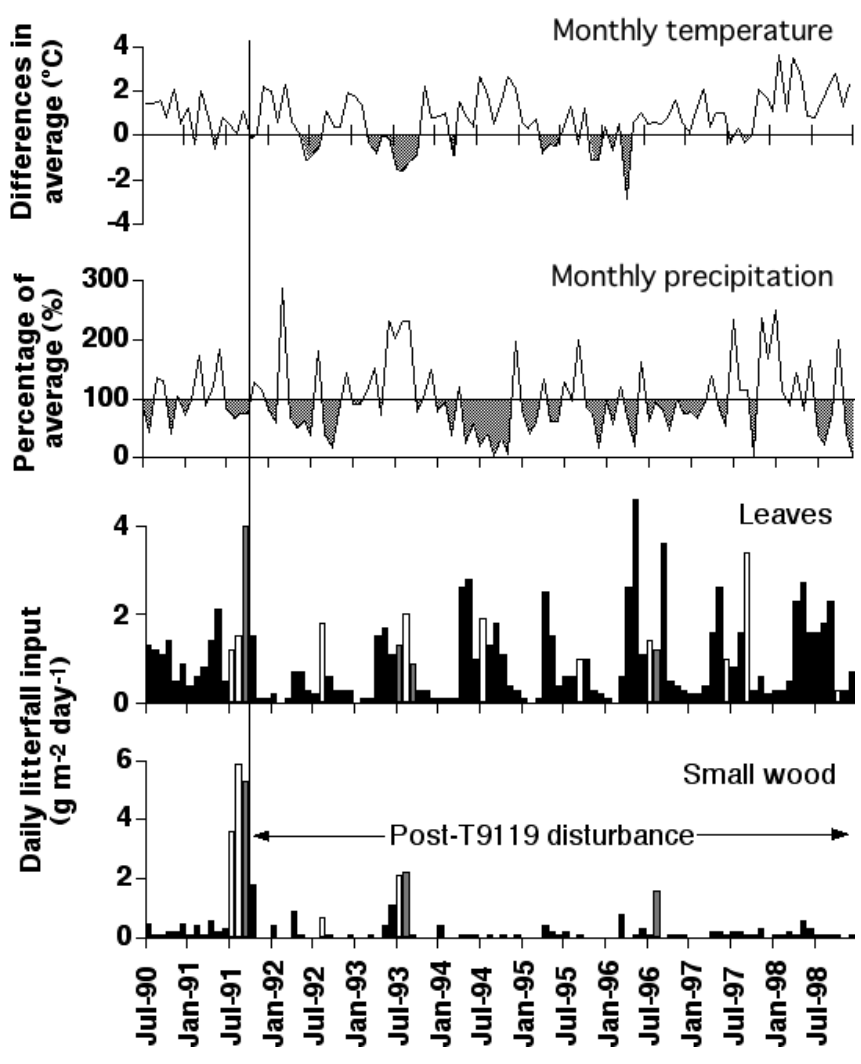

Figure 1. Seasonal change in meteorological data (monthly air temperature and precipitation) and litterfall in a Castanopsis cuspidata coppice before and after the T9119 disturbance. The shaded area of the meteorological data shows the period below the average monthly values. The average monthly temperature and precipitation values of are calculated using 30 years of data from 1961 to 1990 (Kumamoto Local Meteorological Observatory, 1991-1998). The open bars in leaf and small wood input show input with typhoon disturbances; the shaded bars show input due to strong typhoons.

where $L w$ stands for the dry weight of leaves eaten by the tea bagworm, and $E$ stands for the dry weight of the frass. Estimated leaf consumption $(L w)$ in 1990 was estimated to be $1.9 \mathrm{t}^{\mathrm{h}} \mathrm{ha}^{-1}$. Field observations suggest that the consumption of leaves by herbivores was not great, except in late 1990.

\subsection{Recovery of litterfall rates after the $\mathrm{T} 9119$ typhoon disturbance}

Before the T9119 disturbance, the study plot had more than 10000 trees, and about $80 \%$ of these were small trees with less than $4 \mathrm{~cm}$ in DBH (Tab. I). The density of these small trees decreased continuously throughout the period in spite of emergence of many trees after T9119 (i.e. post-T9119 regeneration trees). The decrease in density of small trees was caused by the T9119 disturbance during the first half of the period, and natural thinning during the second half of the period. Over the 8 years following the T9119 disturbance, the tree volume attained $105 \%$ of its pre-T9119 value. Since most of the regenerated trees during the observation period were less than $1 \mathrm{~cm}$ in diameter 


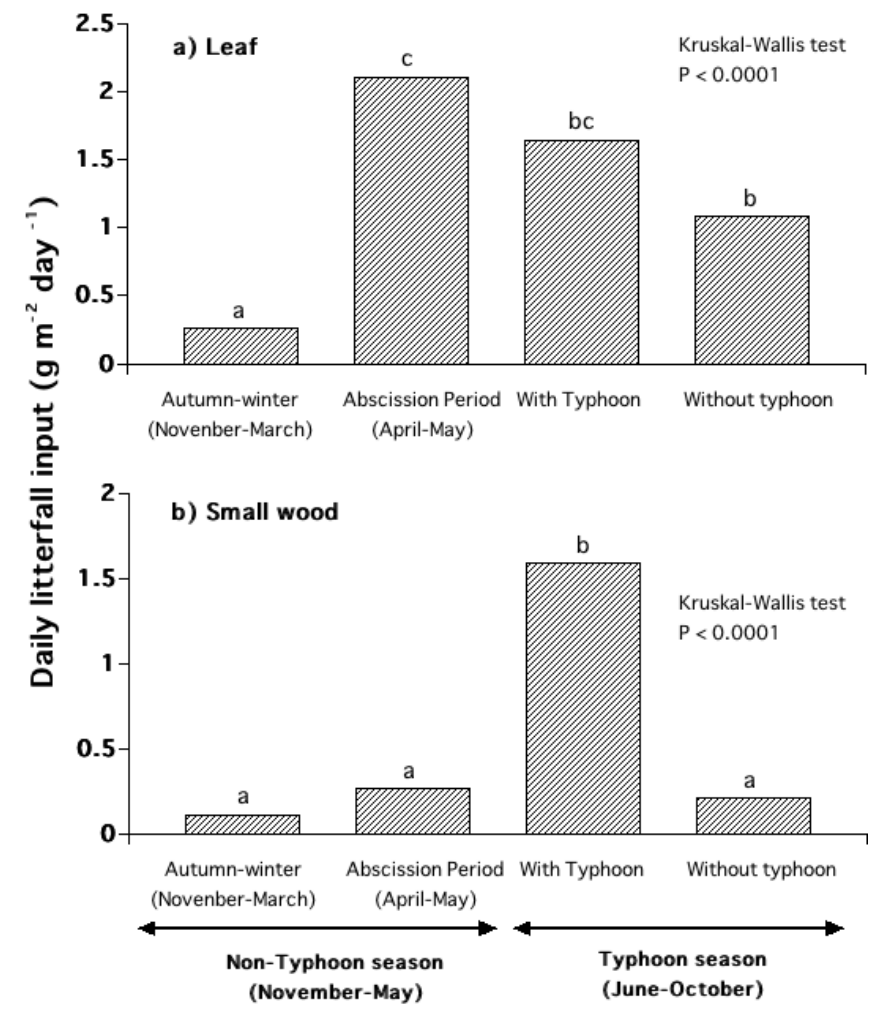

Figure 2. Comparison of litterfall input between different seasons. The average of each category was calculated combining data from the measuring period (1991-1998). The bars with different letters are significantly different from each other (Scheffe's F-test; $P<$ 0.05). The typhoon season (June-October) was classified into two categories: months with typhoon records $(n=14)$ and months without typhoon records $(n=26)$.

(FFPRI, unpublished data), the tree volume increment was formed by previously established trees (i.e., typhoon survivors).

In 1992, the annual leaf input and the first peak of leaf input (April-May) decreased to $35 \%$ and $25 \%$ of the respective preT9119 disturbance values obtained for an adjacent stand (annual leaf input: $4.8 \mathrm{t} \cdot \mathrm{ha}^{-1} \cdot \mathrm{yr}^{-1}$, first peak of leaf input: $1.7 \mathrm{t} \cdot \mathrm{ha}^{-1} \cdot \mathrm{yr}^{-1}$ [11, Kaminaka, personal communication]). The Kruskal-Wallis test showed significant differences in both the annual and the first peak of leaf litter (Fig. 3, annual input: $P<$ 0.0001 , the first input: $P<0.0001)$. Although there were large fluctuations, leaf input increased throughout the observation period (Fig. 3). Based on Dunnett's post-hoc procedure, the annual leaf input increased in 1996 and did not differ significantly from the pre-T9119 value (Fig. 3). At the end of the observation period, seven years after T9119, the annual and first peak inputs had recovered to $94 \%$ and $93 \%$ of the pre-disturbance values, respectively.

\section{DISCUSSION}

Severe wind disturbance (i.e. typhoons or hurricanes) have a significant impact in changing the timing of litterfall input in temperate and tropical forests [7, 20, 25, 45]. My results also

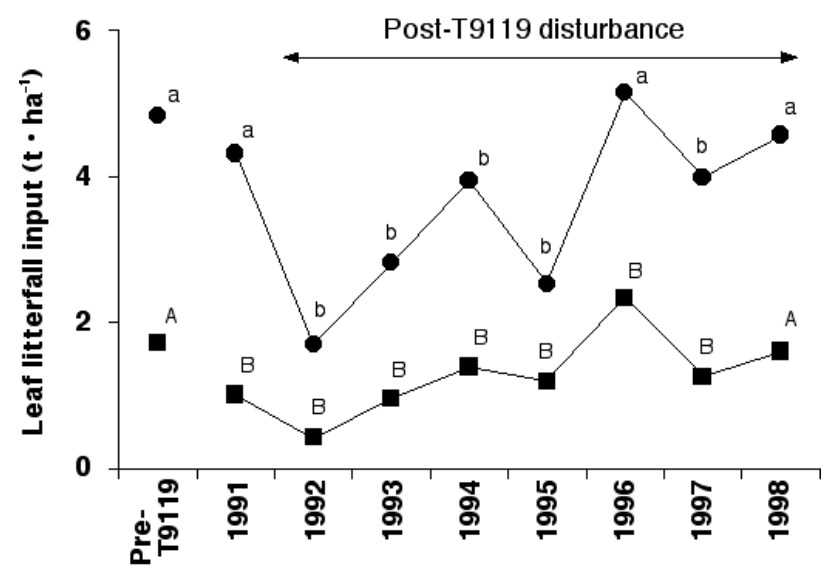

Calendar Year

Figure 3. Fluctuation in annual leaf input and the first peak of leaf input (April-May) before and after the T9119 disturbance. The closed circles are annual leaf input values; the closed squares are the first peak input values. The pre-T9119 values were calculated from Kaminaka [11] and Kaminaka (personal communication). The values labeled with the same letter do not differ significantly at the $95 \%$ level (Dunnett's test) when comparing the pre-T9119 value with annual leaf input since 1991.

indicate that the timing of litterfall in an abandoned Castanopsis coppice changes following a severe typhoon.

The total annual input with the T9119 disturbance was $11.1 \mathrm{t} \cdot \mathrm{ha}^{-1}$, nearly two times higher than the average input in Japanese lucidophyllous forests: $6.3 \mathrm{t} \cdot \mathrm{ha}^{-1}$ [32]. The high input in 1991 was caused by the remarkably high value of small wood. On the other hand, the 1992 input was the lowest during the observation period. Tadaki and Kagawa [38] estimated the lifespan of Castanopsis cuspidata leaves in this stand to be 2 years. This means that defoliation and damage to shoot structure caused by disturbance leads to change in the following year's litterfall production. The drastic decrease in the 1992 input demonstrates how typhoon disturbances affect the litterfall dynamics of forest ecosystems that consist of trees having leaves with a long lifespan. The difference between 1991 and 1992 created the high ratio of maximum to minimum mass in this study (3.9:1), and this ratio is rather high compared with other studies (Tab. III). Tea bagworm infestation, causing the loss of $1.9 \mathrm{t} \cdot \mathrm{ha}^{-1}$ of leaf biomass, was seen in late 1990 . If this infestation had not occurred in the site, vernal input in 1991 might have changed due to undamaged leaf biomass. The study site has a typical coppice stand structure, i.e., evenly sized with a simple canopy stratum. Nagano and Kira [23] showed that a clear-cut peak in leaf biomass occurs in the shallow crown layer of a Castanopsis coppice stand, which is only a few meters thick. In my study, T9119 stressed the canopy layer, concentrating most of the leaf biomass and causing defoliation. Therefore, the high ratio of maximum to minimum mass is probably due to a combination of coppice stand structure and the occurrence of typhoon disturbance.

In lucidophyllous forests, the expansion of new leaves coincides with leaf fall during April to June [26]. The leaf-fall pattern in this study was bimodal. A bimodal leaf-fall pattern has 
Table III. Comparison data of other Castanopsis forests in Japan.

\begin{tabular}{|c|c|c|c|c|c|c|}
\hline Locality & $\begin{array}{l}\text { Total litterfall } \\
\left(\mathrm{t} \cdot \mathrm{ha}^{-1} \cdot \mathrm{yr}^{-1}\right)\end{array}$ & $\begin{array}{l}\text { Max/Min } \\
\text { ratio }\end{array}$ & $\begin{array}{l}\text { Leaf litterfall } \\
\left(\mathrm{t} \cdot \mathrm{ha}^{-1} \cdot \mathrm{yr}^{-1}\right)\end{array}$ & $\begin{array}{l}\text { Measurement } \\
\text { period (Year) }\end{array}$ & Remarks & Reference \\
\hline $\begin{array}{l}\text { Minamata IBP } \\
\text { research area }\end{array}$ & 5.78 & 1.50 & 3.94 & 5 & Castanopsis forest & Nishioka and Kirita [25] \\
\hline Matsue, Shimane & 7.25 & 1.24 & 3.72 & 3 & Castanopsis forest & Katagiri et al. [14] \\
\hline $\begin{array}{l}\text { Kinsakubaru, } \\
\text { Kagoshima }\end{array}$ & 4.91 & 1.11 & 3.60 & 3 & $\begin{array}{c}\text { Castanopsis-Schima } \\
\text { forest }\end{array}$ & Kaminaka et al. [12] \\
\hline Okinawa Island & 7.74 & - & 5.02 & 3 & $\begin{array}{l}\text { Castanopsis-Schima } \\
\text { forest }\end{array}$ & Xu et al. [46] \\
\hline $\begin{array}{l}\text { Mt. Tatsuta, } \\
\text { Kumamoto }\end{array}$ & 9.48 & 1.50 & 4.69 & 6 & Castanopsis forest & Kaminaka [11] \\
\hline Ibid. & 6.13 & 3.00 & 3.75 & 3 & Castanopsis forest & Tadaki and Kagawa [38] \\
\hline Ibid. & 6.00 & 3.85 & 3.63 & 8 & Castanopsis forest & This study \\
\hline
\end{tabular}

also been reported in other evergreen broad-leaved forests, including a Persea thunbergii forest [43], a Quercus acuta forest [10], a secondary forest dominated by Castanopsis cuspidata and Quercus spp. [25], and a subtropical forest dominated by Castanopsis sieboldii and Schima wallichii $[12,46]$. The first peak represents vernal leaf abscission, in which the abscission of old leaves is triggered by the development of new leaves [1]. The second peak was rather irregular and is facultatively shedding [1]. At the level of the individual tree, the Castanopsis trees had a high leaf input peak in the spring and were categorized into a unimodal pattern without typhoon disturbance $[14,26]$. In this study, the seasonal rhythms of leaf input suggest that climatic factors including typhoon disturbance may emphasize the second peak. The combination of high temperature and less precipitation was observed in the summer of 1994 and 1998 (Fig. 1). Kabaya and Suzuki [10] point out that summer droughts may enhance the second leaf input peak in lucidophyllous forests. The summers of 1994 and 1998 in western Japan were dry [16, 42], and may have lead to an emphasis of the second peak. Another clear peak, the highest peak among the second peaks, was recorded on September 1996. This peak may have been caused by a combination of summer drought and typhoon damage from preceding months. Although the small wood input was associated with typhoon disturbances (Fig. 2), there was no clear seasonality compared with leaf input (Fig. 1).

Since most of the small wood collected was in a relatively advanced state of decomposition during the months with strong typhoons (e.g., August 1996), strong typhoons such as T9119 may "clean up" senescent branches that would otherwise fall over a period of several months or years. Lodge et al. [20] point out that hurricanes would generate a significant amount of suspended small wood as well as small wood input to forest floors in Puerto Rico. In the site, suspended small wood on the broken crown may have been caused by T9119 and gradually decomposed throughout the observation period. Alvarez-Sanchez and Guevara [2] report that seasonal winds cause mechanical damage to loosely attached tree parts, forcing them to fall to the forest floor. Although seasonal westerly winds flow from the Asian continent in winter in a monsoon climate [31], no clear peak in small wood input was observed in the winter in this study.
In the 7-year period following T9119, leaf litterfall may not have differed from the pre-typhoon values (Fig. 3). This recovery following T9119 disturbance is characterized by the releafing of trees that survived the disturbance. Both the tree volume and the density of large trees (more than $18 \mathrm{~cm}$ in $\mathrm{DBH}$ ) increased in number during the second half of the observation period (Tab. I). These increments between 1994 and 1998 imply that the leaf biomass of typhoon survivors recover due to re-leafing and that this contributes to the increase in leaf fall mass. Scatena et al. [33] report that leaf fall recovered to $92 \%$ of the pre-hurricane value over the five years following a strong hurricane in a Puerto Rican subtropical forest due to the re-leafing of hurricane survivors and post-hurricane regeneration. Nagao et al. [24] reported that leaf input recovered within three years of thinning young Castanopsis-Persea stands although $40 \%$ of the trees was removed. Tadaki [37] points out that the mean net production (i.e. biomass increment plus litterfall) was not different significantly among the different density plots by the seventh year after thinning. These results imply that recovery after disturbance might be accomplished through re-leafing of the remaining trees. Some pioneer species play an important role in the recovery of litterfall and productivity after disturbance [33]. Although many trees regenerated after the T9119 disturbance between 1991 and 1994 in the site (Tab. I), their contribution to recovery may be small due to their mortality and small size.

Castanopsis cuspidata coppices have a simple stratum structure and a uniform canopy [9, 15, 23]; Castanopsis coppices also have good sprouting ability and high productivity in the warm, humid conditions of southwestern Japan [9, 13, 15]. These traits may induce great variability and lead to the recovery of leaf litter production due to defoliation caused by typhoons. However, old Castanopsis coppices (i.e., 50 to 80 years old) are more susceptible to typhoon disturbances and accelerate the regeneration of shade-tolerant species, such as Distylium racemosum [40, 41]. Bellingham et al. [3] suggest that most tree species in climax lucidophyllous forests may be relatively resistant to typhoon disturbance. Vogt et al. [45] point out that different recovery rates reflect the local dominance of different plant species. The different stand structure of an aging stand may show a different pattern of fine litterfall after typhoon disturbance. Because disturbance-generated input can have a significant 
impact on changing productivity and nutrient cycling in the ecosystem [33, 45], further work is needed to clarify how typhoons affect litterfall dynamics in different successional forest ecosystems.

Acknowledgments: I thank Y. Kominami, S. Saito and D. Nagamatsu for their valuable comments on an early draft; Mrs. M. Hatomura for sample sorting; The Forest Management Group (The Forest Management and Economics Laboratory at that time) at FFPRI, and S. Kaminaka for the use of unpublished data. The comments of two anonymous reviewers greatly improved the quality of the manuscript. This study was partly supported by the Acid Rain Monitoring Project, the Forest Agency, in Japan. Support during the writing of this manuscript was provided by the $\mathrm{CO}_{2}$ Project, administered by the Ministry of Agriculture, Forestry and Fisheries.

\section{REFERENCES}

[1] Addicott F.T., Abscission strategies in the behavior of tropical trees, in: Tomilson P.B., Zimmermann M.H. (Eds.), Tropical trees as living systems, Cambridge University Press, Cambridge, 1978, pp. 381-398.

[2] Alvarez-Sanchez J., Guevara Sada S., Litterfall dynamics in a Mexican Lowland tropical rain forest, Trop. Ecol. 34 (1993) 127142 .

[3] Bellingham P.J., Kohyama T., Aiba S., The effects of a typhoon on Japanese warm temperate rainforests, Ecol. Res. 11 (1996) 229 247.

[4] FFPRI (Forestry and Forest Products Research Institute), Annual Report (1990) of the Acid Rain Monitoring Project, Forestry and Forest Products Research Institute, Tsukuba, 1992 (in Japanese).

[5] FFPRI, Annual Report (1998) of the Acid Rain Monitoring Project, Forestry and Forest Products Research Institute, Tsukuba, 1999 (in Japanese)

[6] Hattori T., Akamatsu H., Takeda Y., Kodate S., Kamihogi A., Yamazaki H., A study on the actual conditions of satoyama (rural forests) and their management, Hum. Nat. 6 (1995) 1-32 (in Japanese with English summary).

[7] Horng F.W., Yu H.M., Ma F.C., Typhoons of 1994 doubled the annual litterfall of the Fu-Shan mixed hardwood forest ecosystems in northeastern Taiwan, Bull. Taiwan For. Res. Inst. New Ser. 10 (1995) 485-491.

[8] Isamoto N., Takamiya T., Factor analysis of forest damages in Oita prefecture by Typhoon 19th (1991.9), Jpn. J. For. Environ. 34 (1992) 98-105 (in Japanese).

[9] Itow S., Secondary forests and coppices in southwestern Japan, in: Holzner W., Wegner M.J.A., Ikushima I. (Eds.), Man Impact on Vegetation, Dr W. Junk Publisher, The Hague, 1983, pp. 317-326.

[10] Kabaya H., Suzuki S., Phenology of tree species by measuring litter fall. I. Patterns of leaf fall of evergreen oak (Quercus acuta) in two stands of the University Forest in Chiba, University of Tokyo, Bull Tokyo Univ. Exp. For. 88 (1992) 135-148 (in Japanese with English summary).

[11] Kaminaka S., Annual variation of litter-fall and seed production in Castanopsis cuspidata forests, Bull. Kyushu Br. Jpn. For. Soc. 43 (1990) 93-94 (in Japanese).

[12] Kaminaka S., Ogata N., Shimoji M., Stand structure of natural evergreen broad-leaved forest in Amami Ohsima Island. V. Annual variation of litterfall at the Kinsakubaru plot, Bull. Kyushu Br. Jpn. For. Soc. 35 (1982) 99-100 (in Japanese).

[13] Kan M., Saito H., Shidei T., Studies of the productivity of evergreen broad leaved forests, Bull. Kyoto Univ. Exp. For. 37 (1965) 55-75 (in Japanese with English summary).

[14] Katagiri S., Yoshimura N., Nagayama Y., Amount of litter fall in a evergreen broadleaf forest reserved in the Rakuzan park, Bull. Fac.
Life Environ. Sci. Shimane Univ. 3 (1998) 5-10 (in Japanese with English summary).

[15] Kira T., Production rates, in: Shidei T., Kira T. (Eds.), Primary productivity of Japanese forests, JIBP Synthesis Vol. 16, University of Tokyo Press, Tokyo, 1977, pp. 101-114.

[16] Kitamura O., Japanese weather highlight in 1994, J. Agric. Meteorol. 51 (1995) 159-165 (in Japanese).

[17] Kitamura S., Murata G., Colored illustrations of woody plants of Japan, Vol. II, Hoikusha Publishing, Osaka, 1984 (in Japanese).

[18] Kumamoto Local Meteorological Observatory (Ed.), Monthly Report of Meteorology, Kumamoto Prefecture, Japan Weather Association Kumamoto Branch, Kumamoto, 1991-1998 (in Japanese).

[19] Kusunoki M., Kawabe Y., Ikeda T., Aoshima K., Role of birds in dissemination of the thread blight disease caused by Cylindrobasidium argenteum, Mycoscience 38 (1997) 1-5.

[20] Lodge D.J., Scatena F.N., Asbury C.E., Sánchez C.E., Fine litterfall and related nutrient inputs resulting from Hurricane Hugo in subtropical wet and lower montane rain forest of Puerto Rico, Biotropica 23 (1991) 336-342.

[21] Mabry C.M., Hamburg S.P., Lin T.C., Horng F.W., King H.B., Hsia Y.J., Typhoon disturbance and stand-level damage patterns at a subtropical forest in Taiwan, Biotropica 30 (1998) 238-250.

[22] Miyawaki A., Vegetation of Japan, Vol. 2, Kyushu, Shibundo, Tokyo, 1981 (in Japanese with German summary).

[23] Nagano M., Kira T., Aboveground biomass, in: Kira T., Ono Y., Hosokawa T. (Eds.), Biological production in a warm-temperate evergreen oak forest of Japan, JIBP Synthesis, Vol. 18, University of Tokyo Press, Tokyo, 1978, pp. 69-82.

[24] Nagao T., Harada H., Meguro S., Annual and seasonal changes in litterfall of an evergreen broad-leaved environmental protection forest created on reclaimed land, Jpn. J. For. Environ. 45 (2003) $7-$ 12 (in Japanese with English summary).

[25] Nishioka M., Kirita H., Litterfall, in: Kira T., Ono Y., Hosokawa T. (Eds.), Biological production in a warm-temperate evergreen oak forest of Japan, JIBP Synthesis, Vol. 18, University of Tokyo Press, Tokyo, 1978, pp. 231-238.

[26] Nitta I., Ohsawa M., Leaf dynamics and shoot phenology of eleven warm-temperate evergreen broad-leaved trees near their northern limit in central Japan, Plant Ecol. 130 (1997) 71-88.

[27] Noda R., The damages of forests in Fukuoka Prefecture by Typhoon No. 17 and No. 19 in 1991, Jpn. J. For. Environ. 35 (1993) 50-59 (in Japanese).

[28] Okutomi K., Conservation of secondary forests, in: Numata M (Ed.), Handbook of Nature Conservation, Asakura Publishers, Tokyo, 1998, pp. 392-417 (in Japanese).

[29] Proctor J., Tropical forest litterfall. I. Problems of data comparison, in: Sutton S.L., Whitmore T.C., Chadwick A.C. (Eds.), Tropical rain forest: Ecology and management, Blackwell, Oxford, 1983, pp. 267-273.

[30] Saito S., Effects of a severe typhoon on forest dynamics in a warmtemperate evergreen broad-leaved forest in southwestern Japan, J. For. Res. 7 (2002) 137-143.

[31] Sasse J., The forests of Japan, Japan Forest Technical Association, Tokyo, 1998.

[32] Satoo T., Temperate broad-leaved evergreen forests of Japan, in Ovington J.D. (Ed.), Temperate broad-leaved evergreen forest, ecosystems of the world. Vol. 10, Elsevier Science Publishers, Amsterdam, 1983, pp. 169-189.

[33] Scatena F.N., Moya S., Estrada C., Chinea J.D., The five years in the reorganization of aboveground biomass and nutrient use following Hurricane Hugo in the Bisley experimental watershed, Luquillo Experimental Forest, Puerto Rico, Biotropica 28 (1996) 424-440.

[34] Shigematsu T., 1998 Surrounding nature - Satoyama, in: Numata M. (Ed.), Handbook of nature conservation, Asakura Publishers, Tokyo, 1998, pp. 255-276 (in Japanese). 
[35] Tadaki Y., Studies on the production structure of forest. VII. The primary production of a young stand of Castanopsis cuspidata, Jpn. J. Ecol. 15 (1965) 142-147.

[36] Tadaki Y., Studies on the production structure of forest. XIV. The third report on the primary production of a young stand of Castanopsis cuspidata, J. Jpn. For. Res. 50 (1968) 60-65.

[37] Tadaki Y., Structure and productivity of young Castanopsis cuspidata forests growing in different stand densities, Bull. Nagoya Univ. For. 14 (1995) 1-24 (in Japanese with English summary).

[38] Tadaki Y., Kagawa T., Studies on the production structure of forest XIII. Seasonal change of litter-fall in some evergreen stands, J. Jpn. For. Res. 50 (1968) 7-13 (in Japanese with English summary).

[39] Tadaki Y., Ogata N., Takagi T., Studies on the production structure of forest. III. Estimation of standing crop and some analyses on productivity of young stands of Castanopsis cuspidata, J. Jpn. For. Res. 44 (1962) 350-359 (in Japanese with English summary).

[40] Taoda H., The succession of Castanopsis cuspidata forest accelerated by the wind damage, in: Papers on plant ecology and taxonomy to the memory of Dr. Satoshi NAKANISHI, The Kobe Geobotanical Society, The Kobe Geobotanical Society, 1987, pp. 379-382 (in Japanese with English summary).

[41] Taoda H., Treatment of evergreen broad-leaved forests dominated by Castanopsis cuspidata in Kyushu, Ringyo Gijyutu 653 (1989) 28-31 (in Japanese).

[42] Ueda T., Weather of Japan in 1998, J. Agric. Meteorol. 55 (1999) 179-185 (in Japanese).

[43] Ueda S., Tsutsumi T., The amount of nutrient elements contained in litterfall of natural evergreen broad leaved forest dominated by
Machilus thunbergii, Bull. Kyoto Univ. Exp. For. 52 (1980) 32-43 (in Japanese with English summary).

[44] Ueno T., Change in terminology of the classification of typhoon and tropical cyclone with reference to their scale and intensity, Kisyo 44 (2000) 4-8 (in Japanese).

[45] Vogt K.A., Vogt D.J., Boon P., Covich A., Scatena F.N., Asbjornsen H., O'Hara J.L., Pérez J., Siccama T.G., Bloomfield J., Ranciato J.F., Litter dynamics along stream, riparian and upslope areas following Hurricane Hugo, Luquillo Experimental Forest, Puerto Rico, Biotropica 28 (1996) 458-470.

[46] Xu X., Tokashiki Y., Hirata E., Enoki T., Nogami K., Ecological studies on subtropical evergreen broad-leaved forest in Okinawa, Japan: litter production and nutrient input, J. For. Res. 5 (2000) $151-156$.

[47] Yamamoto H., Agricultural damages in Kyushu by typhoons 9117 and 9119, J. Agric. Meteorol. 48 (1992) 77-83 (in Japanese).

[48] Yamamoto S., Gap characteristics and gap regeneration in primary evergreen broad-leaved forests of western Japan, Bot. Mag. Tokyo 105 (1992) 29-45.

[49] Yamanaka T., Forest vegetation in Japan, Tsukiji Publisher, Tokyo, 1979 (in Japanese)

[50] Yoda K., Forest ecology, Tsukiji Publisher, Tokyo, 1971 (in Japanese).

[51] Zimmerman J.K., Willig M.R., Walker L.R., Silver W.L., Introduction: disturbance and Caribbean ecosystems, Biotropica 28 (1996) $414-423$. 